Article received on November $15^{\text {th }} 2016$

Article accepted on November $28^{\text {th }} 2016$

UDC: 78.02

78.071.1 Булез П.

\author{
Marija Maglov* \\ University of Arts in Belgrade \\ Faculty of Music \\ $\mathrm{PhD}$ Candidate in Musicology
}

\title{
PAST MUSIC, FUTURE MUSIC: TECHNOLOGY AND MUSIC INSTITUTIONS IN THE 20 ${ }^{\text {TH }}$ CENTURY
}

\begin{abstract}
In his text Technology and the Composer Pierre Boulez writes about new technologies that emerged in the $20^{\text {th }}$ century, primarily created for the purposes of music recording and reproduction, but also established as a means of innovation in electronic and electro-acoustic music practice. Boulez points to two directions where technology and music are in question: conservative historicism and progressive technology, enabling the development of new music material and innovation. By using Boulez's text(s) as a point of departure, the author considers the roles those new technologies had in the development of some musical institutions and questions how institutionalized discourse moulds ideas on the roles music technology should have. The aim of the paper is to discuss how the music of the past was 'conserved' and how the music of the future was created in particular types of music institutions thanks to new technological possibilities.
\end{abstract}

Key words: Pierre Boulez, technology, institution, 'museum', innovation

So we stand at the crossroads of two somewhat divergent paths: on the one hand, a conservative historicism (...) On the other hand, we have progressive technology...

Pierre Boulez, Technology and the Composer ${ }^{1}$

\footnotetext{
* Author contact information: marijamaglov@gmail.com

1 This constructed opposition could be seen as an axis around which the narrative of the text is woven, in Boulez's manner of stating binary principles in his writings that will be discussed further in the paper. The full quotation is as follows: "So we stand at the crossroads of two somewhat divergent paths: on the one hand, a conservative historicism, which, if it does not altogether block invention, clearly diminishes it by providing none of the new material it
} 
As one of the leading personalities of musical life in the $20^{\text {th }}$ century, one that brought new ideas and vigorously defended them, balancing between many aspects of his career as a composer, conductor, musical writer, pedagogue, director of IRCAM. Pierre Boulez certainly marked the musical world as we know it today. ${ }^{2}$ His many activities could be seen as part of his larger project and general mission of fighting for avant-garde musical thought, and against the musical establishment, while he successfully balanced his position in music institutions and between different, at the time, current musical and cultural policies. Thus, when focusing on one aspect of his general output, one cannot overlook others, because they were inevitably intertwined (e.g. composing was followed by auto poetical texts, preparing the repertoire of a certain composer led to writing essays on them; performing activities included performances of new works, but also making a canon of $20^{\text {th }}$ century authors' opuses; his pedagogical efforts followed as an endeavour to promote ideas on the contemporary musical scene, and so on). On the other hand, having in mind Boulez's position and unique understanding of the world surrounding him and the roles different musics had in it, one can draw important conclusions from his writings on particular problems concerning $20^{\text {th }}$ century music. The role of technology in relation to music and in music institutions is one of those problems. As the emergence of different audio technologies and electronic media during the previous century brought many changes in the production and reception of music, it is evident that the thoughts on these particular novelties of such a figure as Boulez is an important issue.

The recording and reproduction of music changed the way music is received, where the individual practice of listening is in question, ${ }^{3}$ but also considering the availability of music to the broader, mass audience. As the musicol-

needs for expression, or indeed for regeneration. Instead, it creates bottlenecks, and impedes the circuit running from composer to interpreter, or, more generally, that from idea to material, from functioning productively; for all practical purposes, it divides the reciprocal action of these two poles of creation. On the other hand, we have a progressive technology whose force of expression and development are sidetracked into a proliferation of material means which may or may not be in accord with genuine musical thought - for this tends by nature to be independent, to the detriment of the overall cohesion of the sound world." Pierre Boulez, "Technology and the Composer", in: Orientations: Collected Writings, Cambridge, Harvard University Press, 1986, 486-494, 489.

2 On Boulez's full activities see: Jean-Jaques Nattiez, “On Reading Boulez”, in: Orientations: Collected Writings, op. cit., 25.

${ }^{3}$ See some comments on the perception of recorded music and the ways it changed listening in: Helmut Rősing, "Listening Behaviour and Musical Preference in the Age of "Transmittied Music", Popular Music, Vol. 4, Performers and Audiences, 1984, 119-149. Available at: http://www.jstor.org/stable/853360, ac: 1. 9. 2013. 
ogist Paul Sanden notes, the emergence of recorded music led to thinking about music in the categories of "live" and "mediatized" music, ${ }^{4}$ and to polemics for and against both. On the other hand, the electronic reproducibility of music and the variety of technologies and electronic music instruments made it possible to pursue new paths and posed challenges in musical invention and composition. Or, better said, once the practice of working with electronic music instruments was established, the quest for the most adequate technologies for the realization of certain poetic ideas could start. However, none of these new phenomena could be discussed without the sense of the musical institutions they were part of. Decisions on music that should be recorded and the disputes on different avant-garde approaches that should be institutionalized ${ }^{5}$ come within the well-established functioning of the musical world and existing structures of music institutions. This is why Boulez's text Technology and the Composer, understood as the IRCAM manifesto, ${ }^{6}$ serves as the starting and most important point for this essay, considering that here, Boulez explained, obviously, his ideas on technology, music and institutions. But, besides that, in this text by Boulez one can see many other referential points important for his discourse (e.g. a critique of the establishment, a critique of certain cultural policies, ideas on the necessity of musicians and scientists working together, etc.).

Also, one of the prominent features of Boulez's writings, present in traces in this particular text, is his dialectical approach. As the musicologist Jean-Jaques Nattiez observes: "If a reader of Orientations were to ask me what I considered to be the fundamental characteristic of Boulez's thinking I should not have any hesitation in saying, 'The binary principle on which it is organized'. (...) Even a more or less random list of pairs of 'palpable categories' without any regard for context, will reveal the general lines along which Boulez's mind works - material/invention, past/future, choice/chance, discipline/freedom (...) (emphasis by M.M.)". 7 Nattiez understands this as he calls it "binary" habit as a "way of approaching the totality of any subject (Italic by J.J.N.)" ${ }^{8}$ Anyhow, a similar

${ }^{4}$ Cf. Paul Sanden, "Hearing Glenn Gould's Body", Current Musicology, No. 88, Fall 2009, $7-34,7$.

5 I am referring to the Boulez and Schaefer disputes in the $60 \mathrm{~s}$, but also on the question of the dominance od IRCAM in front of other music research centers opened in France. More on this in: Georgina Born, Rationalizing Culture: IRCAM, Boulez, and the Institutionalization of the Musical Avant-Garde, Berkeley, Los Angeles, London, University of California Press, 1995, 74-91.

6 Ibid., 97.

${ }^{7}$ For full quotation and Nattiez's list of these binary pairs, see: Jean-Jaques Nattiez, op. cit., 27.

8 Idem. General influences of Frankfurt school, especially Walter Benjamin and Theodor 
division is present in Technology and the Composer, and one of the binary pairings noticeable this time is the one of past and future, as demonstrated in the part of the quotation used as the motto of this essay.

\section{Past music: the 'museum' of music and the technologies of recording and reproduction}

Explaining that the invention in music cannot exist without its reference to the past, be it only the recent past, Boulez nevertheless points out that invention in his time is endangered because of the discrepancies of the composer's musical visions and the sound material he has at his disposal, since "at least at the beginning of this century, our culture has been oriented towards historicism and conservation". 9 This "historicizing culture" has "blocked the evolution of musical instruments", ${ }^{10}$ which made forward compositional thinking and invention in a way harder to realize. Boulez further explains that "the consumption of music has considerably increased" thanks to the availability of music, which led to "a growing boredom with pieces that are frequently heard and repeated, and to search for an alternative repertory - one within the same radius of action as the well-known works and providing a series of substitutes for them". ${ }^{11}$ With this constant search of expected sound (be it in well-known or new works) and also with trends of historically accurate performances, "the 'museum' has become the centre of musical life", pointing, according to Boulez's opinion, to the dangers of culture which "confesses its own poverty so openly", by reconstructing the models of the past and "venerating them like totems". ${ }^{12}$

Boulez's critique of his contemporary culture was maybe most prominently developed in his text Aesthetics and the Fetishists..$^{13}$ Among other things, he states that "an individual reflects the age in which he lives", but that "the only passion shown by the mediocre is their determination to defend ruins". ${ }^{14}$ Here, Boulez also mentions the phrase coined by André Malraux - musée imaginaire - in the context of spreading a consciousness of other art traditions besides that of Western civilization. But, as he observes, the phrase achieved great popularity

Adorno, as well as French (post)structuralism, could be recognized as formative for Boulez's discourse. Cf. Georgina Born, op. cit., 98.

9 Pierre Boulez, "Technology and the Composer", op. cit., 486-487.

10 Ibid., 487.

11 Idem.

12 Idem.

${ }^{13}$ Pierre Boulez, "Aesthetics and the Fetishists", in: Orientations: Collected Writings, op. cit., 31-43.

14 Ibid., 39. 
because "it expresses a deep and widespread feeling that knowledge of the arts - and particularly the plastic arts - has been strikingly extended both historically and geographically."15 This idea of making art available was bound to the technical possibilities of reproduction. Because of Malraux's position as a French Minister of Cultural Affairs, idea found its manifestation in the concept of cultural policy known as the democratization of culture. ${ }^{16}$ Boulez famously declined any cooperation with the French government and taking part in the French cultural scene during Malraux's years in the cabinet, going against his decision to give positions to "reactionary" musicians, which would, according to Boulez, "preserve academicism and its dusty traditions". ${ }^{17}$

Although Malraux's idea of the imaginary museum was originally conceived in relation to the visual arts, its potential for the popularization of music was recognized ${ }^{18}$ and, evidently, it corresponded well with the idea of recording music and making "reproductions" of a variety of the repertoire available to the audience previously unable to get to know it. Thus, the reproduction of music is generally seen as having educational potential. ${ }^{19}$ But, for Boulez, contemporary education is problematic precisely because of historicizing culture and taking models for teaching from "an extremely circumscribed period in the history of music". ${ }^{20}$ This period can be roughly outlined between the $18^{\text {th }}$ and the first half of the $20^{\text {th }}$ century and it is essentially marked by the establishment of the institution of the public concert. It is no coincidence that the institution of the public concert rose to prominence at the same time as the actual museums. As the musicologist J. Peter Burkholder notes: "The building of great concert halls, often with the names of dead composers, the demi-gods of music chiselled into the walls, coincides with the building of the great museums and libraries of Europe and America in the latter $19^{\text {th }}$ century and the first decades of the $20^{\text {th }}$; their parallel function as cultural shrines is clear". ${ }^{21}$ This was the height of culture devoted to the concepts of "masterpiece", "genius" and "Old Masters", which started to

15 Ibid., 37.

16 More on Malraux's policies in: Georgina Born, op. cit., 72.

17 Pierre Boulez, "Why I Say 'No' to Malraux", in: Orientations: Collected Writings, op. cit., $441-444,442$.

${ }^{18}$ Cf. Glenn Gould, "The Prospect of Recording" in: Christoph Cox and Daniel Warner (Eds), Audio Culture: Readings in Modern Music, New York, London, Continuum, 2009.

19 For example, see: Jaques Attali, Noise: The Political Economy of Music, Minneapolis and London, University of Minnesota Press, 1985, 94.

20 Pierre Boulez, "Technology and the Composer", op. cit., 487.

21 J. Peter Burkholder, "Museum Pieces: The Historicist Mainstream in Music of the Last Hundred Years", The Journal of Musicology, Vol. 2, No. 2 (Spring, 1983), 115-134, 118. Available at: http://www.jstor.org/stable/763802, ac. 14.03.2016. 
develop in the late $18^{\text {th }}$ and early $19^{\text {th }}$ century. At the time, the concert audience that was primarily interested in the music of dead composers ("classics") was gradually developed, ${ }^{22}$ and the experience of music as individual, contemplative listening in reverent silence was established..$^{23}$ Thus, by the end of the $19^{\text {th }}$ century, the main goal for the composer was, as Burkholder notes, "to win a place in the museum, hung on the wall next to the 'classics', with the expectation of permanent display". ${ }^{24}$ But, as well as the obvious parallels between concert halls as museums and actual museum institutions, another aspect was crucial, and that is the concept of the musical work. A philosopher of music Lydia Goehr explains the usage of the phrase the "imaginary museum of musical works" as "a musical institution and practice that views its activities and goals for the first time as conceptualized in terms of, and thus directed towards, the production and interpretation of musical work as fine art" ${ }^{25}$ Thus, between the complex discoursive net of knowledge on the concept of musical work and the social circumstances in which the institution of the concert was established, the 'museum' of music happened. Well into the $20^{\text {th }}$ century, the corps of canonical works serving as staples of the concert repertoires, and new works modelled upon those of the past (with neoclassicism being the important line in Western classical music), formed what Burkholder named the "mainstream of $20^{\text {th }}$ century music", whose main characteristic is its historicism, ${ }^{26}$ harshly criticized, as was seen, by Boulez, but also by avant-garde culture in general.

This "mainstream" of music was widely present in radio, television and recordings, as Burkholder notes that "their primary role seems to be to extend the public concert to a wider and even more privatized audience". ${ }^{27}$ In that sense, institutions of the music industry (radio and television stations, recording labels), where artistic music is in question, in a way, create a continuity with the role of the institution of the public concert. What these institutions have in common is their origin in and dependence on the market of bourgeois society, with the hegemony of the music taste of the dominant class. As the musicologist William Weber states, "the new respect for masters was as much a commercial as an artistic phenomenon" developing "directly from the burgeoning industries

\footnotetext{
22 Ibid., 116.

${ }^{23}$ Ibid., 118-119.

24 Ibid., 118.

${ }^{25}$ Lydia Goehr, Imaginary Museum of Musical Works: An Essay in the Philosophy of Music, Oxford, Oxford University Press, 1992, 8

26 J. Peter Burkholder, op. cit., 115-116.

${ }^{27}$ Ibid., 166, footnote 1.
} 
of music publishing, instrument manufacture, and concert management" ${ }^{28}$ The further development of the music market was only boosted with the emergence of recording and reproduction via electronic media. Within capitalist society, especially after World War II, the economy was oriented toward the creation of desire and advertising strategies, because "rising productivity threatened to flood the industrialized economies with a glut of goods" and "technological advances in production and reproduction engender pervasive repetition in a consumer society" ${ }^{29}$ It could be argued that repetitive processes are strongly connected with the capitalist, consumer, mass-media society of the late $20^{\text {th }}$ century ${ }^{30}$ Recording is, it seems, the true product of this society, and the repetitiveness that the recording of the known canonical repertoire entails is part of this culture of repetition. For classical music, the golden age of recorded and broadcasted music was between 1930 and 1980, but it declined afterwards. ${ }^{31}$

Boulez notices that

"there is a very obvious conjunction between the economic processes of a society that perpetually demands that the technology depending on it should evolve, and that it devotes itself notoriously to the aims of storage and conservation. (...) The economic processes have been set to produce their maximum yield where the reproduction of existing music, accepted as part of our famous cultural heritage, is concerned; they have reduced the tendency to monopoly and the rigid supremacy of this heritage by a more and more refined and accessible technology."32

The main problem with "historicizing culture" and its ubiquitous nature is seen by Leon Botstein in

"the processes of recording and broadcasting created unintended and novel commercial and structural barriers to the propagation of new music. An enlarged audience

${ }^{28}$ William Weber, "Mass Culture and Reshaping of European Musical Taste, 1770-1870", International Review of the Aesthetics and Sociology of Music VIII (1977), 6. As quoted in: J. Peter Burkholder, op. cit., 116.

${ }^{29}$ Robert Fink, Repeating Ourselves: American Minimal Music as Cultural Practice, Berkeley, University of California Press, 2005. Fink's study problematizes the culture of repetition. ${ }^{30}$ For a discussion on the political economy of music see: Jacques Attali, op. cit. For an interpretation of Attali's thesis considering the reproduction of music, see: Marija Maglov, "Jacques Attali's Concept of the Political Economy of Music in the Context of the Recording Industry in Former Yugoslavia", in: Žarko Cvejić, Andrija Filipović and Miško Suvaković (eds), European Theories in Former Yugoslavia, Cambridge, Cambridge Scholars Publishing, 2015, 73-78.

31 More on this decline in: Leon Botstein, "Music of a century: museum culture and the politics of subsidy", in: Nicholas Cooke, and Anthony Popple (eds), The Cambridge History of Twentieth Century Music, Cambridge, Cambridge University Press, 2004, 57.

32 Pierre Boulez, "Technology and the Composer", op. cit., 488. 
became familiar with music (...) by playing a record at home over and over again. (...) By the era of the long-playing record and the $\mathrm{CD}$, the familiarity of audiences with a standard canonic repertoire was unparalleled - a familiarity however which was based not on musical texts but on repeated hearings of interpretations from a recorded library". ${ }^{33}$

By the end of the $20^{\text {th }}$ century, the situation was such that "the rupture between the museum culture and the world of new music remains". ${ }^{34}$ In that rupture, it seems that the technologies of recording and reproduction had a significant part, for the sake of "museum" culture.

\section{Future music: avant-garde, technology and institutionalization}

However, these observations are not to say that Boulez himself did not provide any recordings or that he did not engage in performing other music than that of his contemporary avant-garde comrades and his own. On the contrary, Boulez had a very prolific career as a composer and recording artist, but it seems that for him this was a way of conquering positions from which he could go further with his agenda on contemporary music. As could be seen at the beginning of this essay's previous section, Boulez did not negate the past as such, and his concert activity was marked by introducing many 20 th century composers as a way of preparing the audience for the auditive experience of more "advanced" music. The relation of the music avant-garde in general towards the past was explained as its specific nature in comparison to the avant-garde in other arts. ${ }^{35}$ Also, as Georgina Born observes, commenting on Boulez's political position, he argued that "to be an effective revolutionary, you have to enter organizations and change them". 36

Boulez's main object of critique is, as we saw, historicizing the nature of mainstream culture, and, with music, that nature comes with a discourse drawing from romanticism. While criticizing the different "fetishes" of music lovers (such as the "creative message", "sensibility" and "heart" in art, "artistic heritage", "natural order"), Boulez states his own ideas on music, defining it as "at the same time an art, a science and a craft", and claiming that "music is a science

${ }^{33}$ Leon Botstein, op. cit., 52. Author draws on the following publication: Robert Philip, Early Recordings and Musical Style: Changing Tastes in Instrumental Performance, 1900-1950, Cambridge, 1992.

${ }^{34}$ Leon Botstein, op. cit., 54.

${ }^{35}$ On specifics of the avant-garde in music see: Mirjana Veselinović, Stvaralačka prisutnost evropske avangarde u nas, Beograd, Univerzitet umetnosti, 1983, 23-32.

36 Peter Heyworth, "Profiles: Taking leave of predecessors", part 2, The New Yorker, 31 March, 1973, 45-75, 72. As quoted in: Georgina Born, op. cit., 355. 
as much as an art". ${ }^{37}$ The trouble is that "musicians, on the whole, have felt repelled by the technical and the scientific, their education and culture having in no way given them the agility or even the readiness to tackle problems of this kind" which is why they choose from the sound material already available. ${ }^{38}$ However, for Boulez, the main question is: "does the material satisfy my immediate needs?" 39 This is where he sees the potential of progressive technology: "modern technology might be used in the search for a new instrumentation". 40 Therefore, collaboration between musicians and scientists is seen as a necessity, with an imperative to musical thought to learn and appropriate the language of technology but also to "provide the necessary impulse for technology to respond functionally to its desires and imagination". ${ }^{41}$ As the musicologist Mirjana Veselinović-Hofman comments, "Boulez advocates for intellectual engagement in the process of composing but in the juncture of clearly musical starting points and goals". ${ }^{2}$ It is evident that the musical result is always on Boulez's mind, as he states that "the reasoned extension of the material will inspire new modes of thought", but also that "a forceful, demanding idea tends to create its own material". ${ }^{43}$ This was also apparent through the activity of IRCAM, conceived as a grand research centre where scientists and musicians would work together, but where the "music, and Boulez's music above all, remains the main arena for accessing the results of IRCAM". ${ }^{44}$ For example, Boulez's composition Répons was the main representative for the newly developed technologies in IRCAM, such as the $4 \mathrm{X}$ synthesizer. ${ }^{45}$ As a central idea of the direction research should take, the development of real time techniques was emphasized. Boulez explains:

"That was one of my most persistent ideas, which at the outset was by no means understood by everyone. (...) For me, who had had the experience of working as a composer and a performer (...) it was unremitting torture to be a composer who was entirely reliant on the guidance of a pre-recorded tape part which couldn't be altered, except for secondary criteria such as dynamics or spatial layout. (...) As the 1970s

\footnotetext{
37 Pierre Boulez, "Aesthetics and the Fetishists", 32-33.

38 Pierre Boulez, “Technology and the Composer", op. cit., 490.

39 Idem.

40 Ibid., 489.

41 Ibid., 491.

42 Mirjana Veselinović-Hofman, Pred muzičkim delom: ogledi o međusobnim projekcijama estetike, poetike $i$ stilistike muzike 20. veka: jedna muzikološka vizura, Beograd, Zavod za udžbenike, 2007, 72.

43 Pierre Boulez, “Technology and the Composer", op. cit., 492.

44 Georgina Born, op. cit., 91.

45 Ibid., 90-91.
} 
approached, it became clear to me that it was essential for the future of music to come to a union in real time between a virtual score and an instrumental score. Much that I did was with this in mind, and I had di Giugno as an ally, who shared my view entirely".46

Boulez states that the effort to create originality "will either be collective, or it will not be at all. No individual, however gifted, could produce a solution to all the problems posed by the present evolution of musical expression". 47 This is why an institution such as IRCAM was needed - as a centre where fundamental or basic research (as opposed to the commercialized production of technology aimed at the market) could be pursued through teamwork, with its main way of legitimization being to present the musical results achieved. ${ }^{48}$ The launching of IRCAM came at the time of changing cultural policy, after Malraux's departure and President George Pompidou's efforts to reconstruct French artistic life after 1968. ${ }^{49}$ Boulez's strivings to organize IRCAM, and all of his previous activities in different musical institutions, avant-garde or not, accompanied by his writings, were the way of legitimization. Because, for any musical activity to be recognized, and especially for one as radical as Boulez's, it should have its legitimization through theoretical writings published in magazines, performance and educative avant-garde centres (as was Darmstadt) or, in other words, it should be institutionally recognized and supported. This is because, as the art theoretician Miško Šuvaković explains,

"the musical work isn't a thing-in-itself or for itself outside institutions, outside culture and society, but something or anything which can appear under certain historical, musical, artistic, cultural or social circumstances. The musical work, thus, appears on the prepared social scene which makes it possible for something to be recognized and interpreted as music and a musical work, or, music as art, and the musical work as artistic work (italic by M.Š.)" ${ }^{50}$

This means that the institution of the concert, with all the effects it produces (among them, the repertoire of broadcasting and recordings) isn't a given and "natural" state of music, but one of the possible solutions, which means that another could, in convenient circumstances, be established as well. Since the social scene was prepared, with all of Boulez's influences and international rec-

46 Boulez on Conducting: conversations with Cécile Gilly, London, Faber and Faber, 2003, 85-86. Giuseppe di Giugno was an Italian physicist colaborating at IRCAM.

47 Pierre Boulez, "Technology and the Composer", op. cit., 494.

48 Georgina Born, op. cit., 89-91.

49 For a detailed and thorough analyses on French cultural policies and IRCAM's position, see: Georgina Born, op. cit., 66-101.

50 Miško Šuvaković, Estetika muzike, Beograd, Orion Art, 2016, 215. 
ognition, but also with previous activities in the field of electro-acoustic music which, according to Luciano Berio, Boulez tends to forget too easily, ${ }^{51}$ and with a changed cultural policy, IRCAM became the platform for the development of new technologies and music production. Whether it managed to maintain its position as an avant-garde, progressive force, or became, as Paul Griffiths suggests "another electronic music studio, if one that was unusually well financed, and unusually able, therefore, both to embark on grand projects and to present itself to the public", 52 IRCAM remains the intriguing case study of an attempt to execute Boulez's ideas on progressive technology and the future of music.

For any further analysis of technology and music, Boulez's text remains a point of reference, because of the themes it involves regarding the different institutional aspects of music organization that existed throughout the $20^{\text {th }}$ century, but also because its acute observations provide the groundwork for dealing with further questions in relation to his other writings and activities, as well as writings by other authors. On the other hand, Boulez's activities at IRCAM - demonstrated through his musical output, but also through the description of the particular engagement in the creation of appropriate technologies - confirm some observations made by sociologists of technology on the ways that social (in this case - particular musical practice) is integral to the constitution of technological objects, as opposed to the approach focusing just on the treatment of such objects because of the social or cultural significance they produce.$^{53}$ If the question regarding relations between technology and institutions is whether in fact the technology is an institution (because of "the embedding and freezing choices within scientific and technical systems" making the social aspect invisible), ${ }^{54}$ what does it mean for the analyses of music institutions concerned with technology, being those of recording or those of researching innovative technological approaches? It seems that the problems Boulez pointed to and solutions he proposed leave enough work to be done and understood in order to approach the questions of production and reception of music in the $20^{\text {th }}$ century.

51 Luciano Berio, Two Interviews (with Rossana Dalmonte and Bálint András Varga), London, New York, Marion Boyars, 1985, 128.

52 Paul Griffiths, Modern Music and After, Oxford, Oxford University Press, 2010, 335.

53 Cf. Trevor Pinch, Technology and institutions: living in a material world, Springer Science and Business Media B.V.2008, published online 10 July 2008, 462. The Pinch case study revolves around the development of the Moog synthesizer.

54 Ibid., 467. 


\section{References}

Attali, Jaques, Noise: The Political Economy of Music, Minneapolis and London, University of Minnesota Press, 1985.

Berio, Luciano, Two Interviews (with Rossana Dalmonte and Bálint András Varga), London, New York, Marion Boyars, 1985.

Born, Georgina, Rationalizing Culture: IRCAM, Boulez, and the Institutionalization of the Musical Avant-Garde, Berkeley, Los Angeles, London, University of California Press, 1995.

Botstein, Leon, "Music of a century: museum culture and the politics of subsidy", in: Nicholas Cooke, and Anthony Popple (Eds), The Cambridge History of Twentieth Century Music, Cambridge, Cambridge University Press, 2004.

Boulez, Pierre, "Technology and the Composer", in: Jean-Jacques Nattiez (Ed.), Orientations. Collected Writings. Cambridge, Harvard University Press, 1986, 486-494, 489.

Boulez, Pierre, "Aesthetics and the Fetishists", in: Ibid., 31-43.

Boulez, Pierre, "Why I Say 'No' to Malraux", in: Ibid., 441-444, 442.

Boulez on Conducting: conversations with Cécile Gilly, London, Faber and Faber, 2003.

Burkholder, Peter, "Museum Pieces: The Historicist Mainstream in Music of the Last Hundred Years", The Journal of Musicology, Vol. 2, No. 2 (Spring, 1983), 115-134, 118. Available at: http://www.jstor.org/stable/763802, ac. 14.03.2016.

Fink, Robert, Repeating Ourselves: American Minimal Music as Cultural Practice, Berkeley, University of California Press, 2005.

Goehr, Lydia, Imaginary Museum of Musical Works: An Essay in the Philosophy of Music, Oxford, Oxford University Press, 1992.

Gould, Glenn "The Prospect of Recording" in: Christoph Cox and Daniel Warner (Eds), Audio Culture: Readings in Modern Music, New York, London, Continuum, 2009.

Griffiths, Paul, Modern Music and After, Oxford, Oxford University Press, 2010.

Maglov, Marija, "Jacques Attali's Concept of the Political Economy of Music in the Context of the Recording Industry in Former Yugoslavia", in: Žarko Cvejić, Andrija Filipović and Miško Šuvaković (Eds), European Theories in Former Yugoslavia, Cambridge, Cambridge Scholars Publishing, 2015.

Nattiez, Jean-Jaques, “On Reading Boulez", in: Jean-Jacques Nattiez (Ed.), op. cit., 25.

Pinch, Trevor, "Technology and institutions: living in a material world", Springer Science and Business Media B.V.2008, published online 10 July 2008, 462.

Rösing, Helmut "Listening Behaviour and Musical Preference in the Age of "Transmittied Music", Popular Music, Vol. 4, Performers and Audiences, 1984, 119-149. Available at: http://www.jstor.org/stable/853360, ac: 1. 9. 2013.

Sanden, Paul, "Hearing Glenn Gould's Body", Current Musicology, No. 88, Fall 2009, 7-34.

Veselinović-Hofman, Mirjana, Pred muzičkim delom: ogledi o međusobnim projekcijama estetike, poetike $i$ stilistike muzike 20. veka: jedna muzikološka vizura, Beograd, Zavod za udžbenike, 2007.

Weber, William "Mass Culture and Reshaping of European Musical Taste, 1770-1870", International Review of the Aesthetics and Sociology of Music VIII (1977), 6.

Šuvaković, Miško, Estetika muzike, Beograd, Orion Art, 2016. 